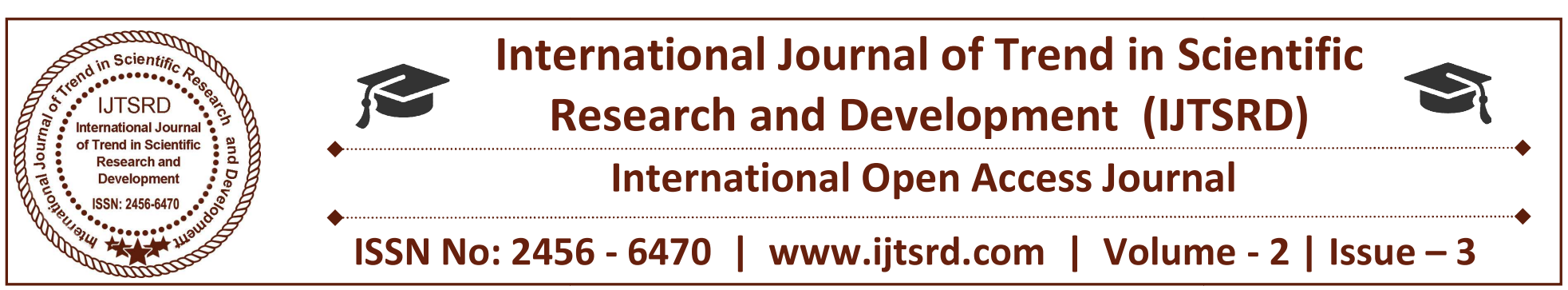

\title{
Impact of Abusive Supervision on Employee Turnover Intention: The Moderating Effect of Emotional Exhaustion
}

\author{
Mr. Sher Alam Khetran \\ Faculty of Management Sciences, \\ International Islamic University, \\ Islamabad, Pakistan
}

\begin{abstract}
Mr. Sikandar Wali
Faculty of Management Sciences, COMSATS Institute of Information Technology, Wah Campus, Pakistan
\end{abstract}

\section{ABSTRACT}

The research was aimed to find out the impact of abusive supervision on turnover intention and to see how the moderating role effect by the abusive supervision and leads toward turnover intention i.e. emotional exhaustion. A total of 60 responses were gathered for the analysis of the study. The analysis has to be done through filling up questionnaires from the respondents. Statistical package of social sciences (SPSS) was implemented to get the result. The result finds that emotion exhaustion moderates the relationship between the dependent and independent variable. The nexus between abusive supervision and turnover intention turn out to be positively significant. An optimistic relation was found between the abusive supervision and the moderating variable.

\section{Keywords: Abusive supervision; emotional} exhaustion; turnover intention

\section{INTRODUCTION}

According to (Mathieu and Babiak, 2016) there are three main mediums which give organization competitive benefits in the aggressive competition atmosphere. These include human capital, organizational capital and physical capital resource. Human capital is the most important for an organization among the factors. Human capital plays pivotal role in the performance of an organization, contributes extremely in growth and supports the competitive benefit for the firm. Pradhan and Jena (2017) emphases on the effective management of employees which leads the firm in leadership position in industry. Emotional exhaustion is the interceding factor which can be affected by the abusive supervision and leads the turnover intention. Study shows that researcher focuses on the impact of abusive behavior on turnover intention.

Furthermore, supervision means to lead and control the employees in an organized manner (Kelloway \& Leblanc, 2002). Abusive supervision refers to the unfriendly behavior and no physical attitude toward the lower staff. Abusive behavior affects both employer and employee negatively (Milam, Spitzmueller \& Penney, 2009). Unwelcomed behaviors have a disapproving impact on the employee's attitude and also have influence on the employee performance like organizational deviance and organizational citizenship behaviors (Tepper, 2007). These outcomes focus on that how managerial actions impact the employee behavior and attitude by examining their desired and annoying managerial response.

Moreover, the substantial part of this particular study is abusive supervision which can lead the workplace aggressive environment to workplace violence (Baron \& Neuman, 1998). Abusive behavior indicates that it 
affects the expected outcome of an organization. Abusive supervision may not affect as much to the organization but it is more likely to leave long lived abrasions. Abusive supervision incurs to those companies in terms of frequent turnover, low productivity and employee's absenteeism. Abusive supervision has adverse effects on the consequence of workers at workplace which creates interpersonal perverseness and also it has effects on lower job performance.

Abusive supervision is linked to emotional exhaustion as a workplace stress. The relation between emotional exhaustion and abusive supervision is mostly deduced from the abusive supervisor and abused subordinate interpersonal grievances. The annoying result may have destructive effects on the abused minor which then results in low energy and low emotional resources to deal with such type of situation. The subordinate's abusive feelings have a double effects on him such that abusive bosses not only make the abused employees hopeless and less motivated about forthcoming outcome but also decrease his/her mental resources leading to greater emotional exhaustion in the employees. The diminution of employee's mental stress and emotion that affects the psychological association in organization considered as emotional exhaustion. The employee sense fatigued, tired or their sensitive energies are tired, determination of such feelings becomes chronic and long lasting hence the workers are considered as emotionally exhausted. It usually experienced in human service organization (Maslach, 1981, 1986). The organizational objectives suffer very badly due to the emotional exhaustion because employee can't concentrate on his work and take expected interest to their work and also become worse when the feelings become chronic. Mental wear and tear as the tiredness not the emotional exhaustion, even though the concepts are very similar (Halbesleben et al., 2004).

Turnover intention is very difficult for the organization. It has a great impact in the sense of cost which can be in any form. Firm performance depends on turnover when turnover rate decrease, organization become more productive and vice versa. Motivation or incentive of turnover intention is the multidimensional. No single factor contributes to the employee's attitude towards turnover. Reduction in organizational commitment, job satisfaction, and judgment of substitutes are approximately of the organizational factor that creates turnover intention among employees. Organizational promise and turnover intention could affect human resource policies and practices. Emotional exhaustion has been linked with different worked outcomes like absenteeism, withdrawal, low commitment and intention to leave (Maslach \& Leiter 2009). The increase in emotional exhaustion creates to concentrated effectiveness and low output. Concurrently, high level of commitment leads to low turnover intention.

\section{LITERATURE REVIEW}

\section{A. Abusive Supervision}

Teper (2000) had contributed in the field of abusive supervision. He incorporated that the number of workers of any company sense that their managers and bosses are getting involve in antagonistic actions with them that includes both non-verbal and verbal. Usually it is imaginary that mistreatment to attendants should experience renowned mental problems and sufferings, i.e. unhappiness, exhaustion, nervousness and occupational stress (Teper, 2007). Though, (Teper 2007) highlights that all the affiliates could not be operated similarly by the abusive system of employees and management e.g. abusive supervision can be reduced through defensive strategies (Teper, Moss, Lockhart \& Carr 2007). In short, employee judgment of intolerable management also has damaging results for links i.e. destructive effects on proper each task valuations, task performance, and managerial citizenship behavior (Zelars, Teper, \& Duffy, 2002). Concluding all these significances, (Schyns and Schiling, 2013) presented a metaanalysis review and the consequences were connected with consciousness of abusive supervision. In this literature when subordinates grieve from rude management, it can stop them from connecting well with other and their works and serving them. Abusive supervisors will indulge with other staff to maintain stability between harmful treated subordinates and the others. Interactive nonconformity can be raised due to abusive supervision which can create negative impact on job presentation (Liu et al, 2010; Khan et al, 2011). Organization subordinates want to be fortified to their manager through working hard, sincerely, fairly and they treat their colleagues with consideration \& respect. Employees can involve in bad behavior at their workplace when they are ill-treated. Due to this employee shows negative attitude to their work which will be less productive for any organization. Some researcher thinks that job stress increase when individual have the conflict with the current happening in the organization. Stress can increase 
tension and pressure on the employee through which they can't focus on their work properly. According to Kumar and Ghadially (1986) relational trust, disaffection and sensation are very essential variable for job performance. It will be very painful for any worker when he faces bad nonconformity from their past experience in present workplace. Emotional exhaustion increases through uncertainty and Struggle. Role clash has a great impact on the emotional fatigue (Boles et al, 1997). According to Brown and Peterson (1993) emotional exhaustion has negative effect on job performance and organizational commitment which can be reduced through interactional fairness and the positive consequences of the justice. Psychological sufferings and work life clashes increase through the unfair treatment atmosphere. Unceasing obligation are the basic needs of workers for managerial addition (Meyer \& Allen, 1991). Administration unjust environment feel the workers that their work is not good enough and their contribution all in vain (Konovsky \& Cropanzano, 1991).

With an in-depth study of literature, it can be established that the relation between emotional exhaustion \& abusive supervision is mostly inferred from the abusive supervisor and mistreated subordinate interpersonal grievances (Javeed et al., 2018). The unwanted result may have negative effects on the abused subordinate which can result in low emotional assets to deal with such type of situation. According to Tepper et al. (2017) subordinates are emotionally exhausted when feeling that they are having no more resources to control, forecast and understand the stressor that hit them. When employees become hopeless of future outcome from interaction with their manager, they will try to escape from using the energy and resources in taking feedback from their supervisor.

\section{B. Turnover Intention}

The personnel of any organization is supposed to maneuver on the far side borders of the organization it states to turnover (Rahman \& Naz, 2013). Within the withdrawal knowledge method, there are three parts of turnover intention. First one states that once staff of organization has feelings of quitting the task. Second once worker commits to go looking for additional new jobs and third once quit the job (Carmeli \& Weisberg, 2006). Turnover intention of staff is of main interest within the management literature. It is doubtless that if they acknowledge relationship injustice, when an abusive superordinate ponders future exploitation of an equivalent sort, they are going to move for employment elsewhere. As per (Zapf \& Gross, 2001), as time goes on, abusive supervising grows and exaggerates. It's going to lead a conflict between the staff and so reach at part of magnification. Abusive management distresses Organization Citizenship Behavior OCB and performance of task in an exceedingly negative approach, whereas it transmits in an exceedingly positive manner to turnover rate and emotional exhaustion (Liu et al, 2009). In keeping with (Teper, 2000) abusive management has created negative impacts on turnover intention. In his study (Teper, 2000) used the structural fairness theory for the analysis of abusive management by thought of interactive fairness and same as structure justice and therefore the consequences of the justice happen completely like structure commitment, job satisfaction associated life satisfaction on the opposite hand an surroundings that is unjust the results can occur within the sort of conflict relating to work life and mental suffering. Once organizations are encircled with the surroundings that is unjust then the personnel sense that their work isn't acknowledge and doesn't appreciated by their directors and is unworthy for the business (Konovsky \& Cropanzano,1991). Then the outcomes disclosed a considerable positive relationship between the employees' geographical point deviance and abusive management. Researchers additionally conclude that the various psychological aspects of the workforces additionally underwrite reaction towards the abusive management of the administration. The usually found angle that may be comprised within the abusive management square measure the slight, inconsiderate action, breaking guarantees, rudeness and the public criticism (Bies, 2000).

Jannefer et al. (2010) originated within the analysis that the staff involvement in harmful work perspective will ultimately lead to the association with relative clashes of organization. Namie, (2007) recommends that the abusive oversight of staff tips to the top of gifted and tireless staff within the voluntary or involuntary manner. Staff managing the abusive behavior would negatively effect on the organization standing and image. The sensation of immobilized results into the mental frustration and consequences the violent behavior (Bennet, 1998). Some lecturers ponder mental pathology as a stress. Same pressure could produce variety of great outcomes substantial factors embody stress period of stress intensity. (Kumaar \& Ghadialy, 1986) studied completely 
different variables shared feeling, trust and alienation concerning the performance of their jobs. In step with Ferris et al. (1996) nearly equivalent outcomes that the structure politics and therefore the job anxiety square measure by trial and error connected. Gilimore (1996) tries to demonstrate that the aggressive perspective within the setting of the organization that's extremely returns team's dissonance and therefore the individual conflicts. Erain (2000) directed a study on the connection among the aggressive behavior politics and job stress within the work. Reconciling character of Job, Personnel develop discontent as they discovery any pessimistic nonconformity from their performances of previous job in their gift job.

\section{Emotional Exhaustion}

Emotional fatigue shaped by the task acting has two main causes, initial is once the employees feel emotional dissonance and work depression and second once the resources related to the tasks square measure moved out even once the employee has given sincere effort. If internal feeling of the staff is connected with the looks then there will be less emotional dissonance. Turnover is often expensive issue for organizations as a result of with the turnover they have to recruit, offer trainings and develop the new force. (Alexender, Blom and Nicholas, 1994). The foremost supervisors of the organization adopt the abusive actions there will be a likelihood to a lot of structure fairness and fairness would be established that finally returns within the style of turnover (Teper, 2000).

Firm Citizenship Behavior OCB is that the development that's somewhat outside the minimum stage of the work obligation like promotion of the workfellow, internal teams of organization and geographic point as an entire (Kahn et al., 1999). Several researches disclosed that the most issue that influences the structure citizenship behavior is culture (Coyne \& Ong, 2007). If the Individual United Nations agency square measure acting structure citizenship behavior square measure align with their values (Shamir 1996).

\section{THEORETICAL FRAMEWORK}

The theoretical framework is the base of any study. The hypotheses being proposed in the study based on the framework ae shown below.

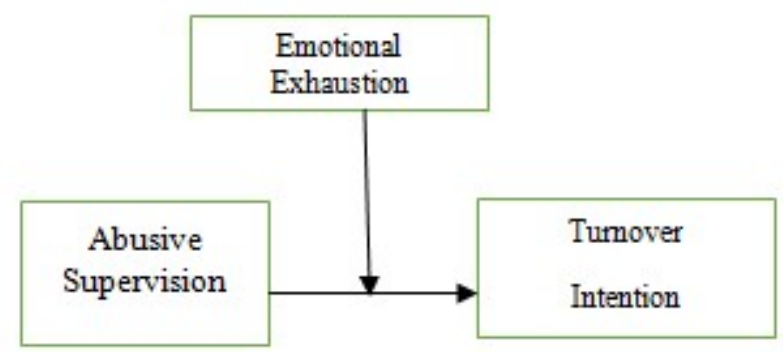

$\mathbf{H}_{1}$ : There is a positive and significant relationship between abusive supervision and emotional exhaustion.

$\mathbf{H}_{2}$ : Emotional exhaustion has a moderating effect in the relationship between abusive supervision and turnover intention.

\section{III.METHODOLOGY}

The quantitative techniques were utilized to conduct the analysis, which is predicated on strictly statistical nature of analysis. Every discipline features a set of tips and procedures, that square measure vital to conduct a good analysis. The survey analysis technique was utilized in suggestion with a range of a hypothesis. The survey analysis technique is formed from analysis procedure that is employed for knowledge assortment. All those sociological strategies and their application are mention below.

\section{A. Research Design}

In this study, data were gathered through quantitative research which uses the numerical analysis. The main purpose of using this technique was to help the researcher to know the main cause and effect relationship of independent and dependent variable. Through this design we can also test the hypothesis.

\section{B. Target Population}

In this study the Component of analysis refers to those people who are recently working in a private limited organization. The target population age starts from 21 to 30 and above, which are recently working in under the supervision of their boss.

\section{Sampling Technique}

In this paper the purposive sampling was used to collect the data from sample population. Purposive sampling is a kind of non-probability sample that the assistant deliberately chooses specific fundamentals for presence in the paper in order to certify that the essentials will have definite features appropriate to the study. The target population was people who are working in an organization, therefore to access the 
particular population purposive sample were constituted to match the criteria of the study.

\section{Tools for Data Collection}

The executing is the most typically methodology for survey. The tactics were found to be the foremost applicable for data collection. The data gathering tools will be collect through face to face and distribution of question paper. If respondent was facing problem to understand any question then interviewer provide to the respondent. This methodology was utilized in the prevailing study due to the following reasons; essential for gathering of such form of data. Furthermore, the researcher should produce an instantaneous and private contact with the respondents so as to urge authentic info.

\section{E. Techniques for Data Collection}

Questionnaires were used for data collection in which mainly addressed the people who are recently working in organization.

\section{F. Data Analysis}

In this paper descriptive \& inferential statistical method was accustomed analysis the data. The descriptive statistical is the procedure that is employed to analysis the odds and frequencies and inferential statistical is that the procedure which is employed for chi square, hypothesis testing in the Statistical Package for business studies (SPSS) is one of the amongst general software for the business studies.

\section{IV.ANALYSIS AND INTERPRETATION}

This section presents the analysis of the data being collected through questionnaire. The analysis is done to probe into whether any valid relationship exists among the variables or not.

\begin{tabular}{|l|l|}
\hline Table No 1: Reliability Statistics \\
\hline Cronbach's Alpha & N of Items \\
\hline 857 & 3 \\
\hline
\end{tabular}

Reliability statistics is used to know whether our questioners and their material were clear and acceptable. The reliability test for each instrument was conducted by the reliability statistic. Cronbach's alpha is one of the selection criteria to show the internal consistency of reliability coefficient. The results shown in Table 1 exhibit 0.857 Cronbach's alpha value which is greater than the minimum value. The minimum reliability with alpha is 0.6 but in our study Cronbach's alpha is greater than minimum value which show the measures are deemed reliable.

\begin{tabular}{|c|c|c|c|c|}
\hline \multicolumn{5}{|c|}{ Table No 2: Item-Total Statistics } \\
\hline & \begin{tabular}{|l|} 
Scale \\
Mean \\
Item \\
Deleted
\end{tabular} & \begin{tabular}{l|l} 
Scale \\
if $\mid$ Variance i \\
Item \\
Deleted
\end{tabular} & $\begin{array}{l}\text { Corrected } \\
\text { Item-Total } \\
\text { Correlation }\end{array}$ & $\begin{array}{l}\text { Cronbach } \\
\text { 's Alpha if } \\
\text { Item } \\
\text { Deleted }\end{array}$ \\
\hline AS & 7.193 & 1.995 & .681 & .844 \\
\hline $\mathbf{E E}$ & 7.220 & 1.616 & .775 & .761 \\
\hline TI & 6.733 & 1.925 & .747 & .787 \\
\hline
\end{tabular}

In the above Table 2 it is shown that three variants of the three variables which have different value with the Cronbach's alpha if the item deleted. The comprising between three variables abusive supervision has high value which is .844 and turnover intention has Cronbach's alpha .787 and emotional exhaustion has .761 Cronbach's alpha value.

Table No 3: KMO and Bartlett's Test

\begin{tabular}{|l|l|l|}
\multicolumn{2}{l}{$\begin{array}{l}\text { Kaiser-Meyer-Olkin } \\
\text { Measure of Sampling } \\
\text { Adequacy. }\end{array}$} & .598 \\
\hline \multirow{2}{*}{$\begin{array}{l}\text { Bartlett's Test } \\
\text { of Sphericity }\end{array}$} & $\begin{array}{l}\text { Approx. } \\
\text { Chi-Square }\end{array}$ & 48.016 \\
\cline { 2 - 3 } & Df & 10 \\
\cline { 2 - 3 } & Sig. & .000 \\
\hline
\end{tabular}

The Table 3 depicts KMO and Bartlett's test values for the studu. Kaiser-Meyer-Olkin (KMO) is used to measure of sampling adequacy. According to (Hair et al, 2010) the value of KMO for indicating the suitability of the use of exploration factor is must be 0.70 and above, moderate value must be from 0.50 to 0.70. Our value lies in between which is .598 so KMO measure of the study for sampling adequacy is accepted. The BTOS value of significant is .000 which shows the appropriateness of factor analysis.

\begin{tabular}{|l|l|l|}
\hline \multicolumn{3}{|l|}{ Table No 04: Communalities } \\
\hline & Initial & Extraction \\
\hline AS1 & 1.000 & 0.750 \\
\hline AS2 & 1.000 & 0.755 \\
\hline AS3 & 1.000 & 0.503 \\
\hline AS4 & 1.000 & 0.588 \\
\hline AS5 & 1.000 & 0.660 \\
\hline
\end{tabular}

The ideal values of communalities should be greater than 0.5 . In the above table 5 , it is evident that the 
International Journal of Trend in Scientific Research and Development (IJTSRD) ISSN: 2456-6470

values of communalities is greater than 0.50 which exhibits that so there is no need to delete any item.

\begin{tabular}{|l|l|l|}
\hline $\begin{array}{l}\text { Table No 5: KMO and Bartlett's } \\
\text { Test }\end{array}$ & \\
\hline $\begin{array}{l}\text { Kaiser-Meyer-Olkin Measure of } \\
\text { Sampling Adequacy. }\end{array}$ & 0.698 \\
\hline \multirow{3}{*}{$\begin{array}{l}\text { Bartlett's Test } \\
\text { Sphericity }\end{array}$} & $\begin{array}{l}\text { Approx. } \\
\text { ofhi-Square }\end{array}$ & 65.064 \\
\cline { 2 - 3 } & Df & 10 \\
\hline & Sig. & 0.000 \\
\hline
\end{tabular}

In the prospective of emotional exhaustion Table 5 shows KMO measure of sampling adequacy is 0.698 which is appropriate sampling adequacy and BTOS value of significant is 0.000 which is appropriateness of factor analysis.

\begin{tabular}{|l|l|l|}
\hline \multicolumn{3}{|c|}{ Table No 06: Communalities } \\
\hline & Initial & Extraction \\
\hline EE1 & 1.000 & 0.598 \\
\hline EE2 & 1.000 & 0.660 \\
\hline EE3 & 1.000 & 0.768 \\
\hline EE4 & 1.000 & 0.626 \\
\hline EE5 & 1.000 & 0.794 \\
\hline
\end{tabular}

The communalities of the items of emotional exhaustion are well above the ideal value of 0.5 which leaves no further requirement for deleting any item. All the values are shown in Table 6.

\begin{tabular}{|c|c|c|c|}
\hline \multicolumn{4}{|c|}{ Table No 07: KMO and Bartlett's Test } \\
\hline \multirow{2}{*}{\multicolumn{2}{|c|}{$\begin{array}{l}\text { Kaiser-Meyer-Olkin } \\
\text { Sampling Adequacy. } \\
\end{array}$}} & Measure & $\mathbf{f} \mid 0.641$ \\
\hline & & \begin{tabular}{l|l} 
Approx. \\
of Chi-Square
\end{tabular} & 79.916 \\
\hline \multirow{2}{*}{$\begin{array}{l}\text { Bartlett's } \\
\text { Sphericity }\end{array}$} & \multirow{2}{*}{ Test } & Df & 6 \\
\hline & & Sig. & 0.000 \\
\hline
\end{tabular}

The KMO measure of sampling adequacy for the turnover intention is 0.641 and BTOS of significant is 0.000 which is suitable of factor analysis. Both the values are appropriate for the factor analysis. In the above table 8 presents the values of communalities is greater than .50 which confirms the goodness of all the items.

\begin{tabular}{|l|l|l|l|l|l|l|l|}
\hline \multicolumn{2}{|c|}{ Table No 9: Descriptive Statistics } & \multicolumn{3}{|c|}{ Demographics) } \\
\hline \multicolumn{2}{|l|}{} & Gender & Age & Occ & Quali & Marital & Family \\
\hline \multirow{2}{*}{$\mathbf{N}$} & Valid & 60 & 60 & 60 & 60 & 60 & 60 \\
\cline { 2 - 8 } & $\begin{array}{l}\text { Missi } \\
\text { ng }\end{array}$ & 0 & 0 & 0 & 0 & 0 & 0 \\
\hline Mean & 1.00 & 1.53 & 1.97 & 1.78 & 1.12 & 1.63 \\
\hline Median & 1.00 & 1.00 & 2.00 & 2.00 & 1.00 & 2.00 \\
\hline $\begin{array}{l}\text { Std. } \\
\text { Deviation }\end{array}$ & .000 & .623 & .181 & .666 & .324 & .486 \\
\hline Minimum & 1 & 1 & 1 & 1 & 1 & 1 \\
\hline Maximum & 1 & 3 & 2 & 3 & 2 & 2 \\
\hline
\end{tabular}

In the above statistics table the average of gender is 1 , age is 1.53 , occupation is 1.97 , qualification is 1.78 , marital is 112 and family is 1.63 which is quite good. Median of gender is 1 , age is 1 , occupation is 2 , qualification is 2 , marital is 1 , family is 2 which is in between and quite good. Std. Deviation of gender is .000 , age is .623 , occupation is .181 , qualification is .666 , marital is .324 and family is .486 .

\begin{tabular}{|c|c|c|c|c|}
\hline \multicolumn{5}{|c|}{ Table No 10: Descriptive Statistics (Variables) } \\
\hline & & $\mathbf{A S}$ & $\mathbf{E E}$ & TI \\
\hline \multirow{2}{*}{$\mathbf{N}$} & Valid & 60 & 60 & 60 \\
\hline & Missing & 0 & 0 & 0 \\
\hline \multicolumn{2}{|c|}{ Mean } & 3.380 & 3.353 & 3.840 \\
\hline \multicolumn{2}{|c|}{ Median } & 3.400 & 3.500 & 3.800 \\
\hline \multicolumn{2}{|c|}{ Std. Deviation } & .7128 & .8121 & .7023 \\
\hline \multicolumn{2}{|c|}{ Minimum } & 2.0 & 1.6 & 2.2 \\
\hline \multicolumn{2}{|c|}{ Maximum } & 4.8 & 4.8 & 5.0 \\
\hline
\end{tabular}

In above table the average of abusive supervision is 3.380 and maximum is 4.8 which are quite good. The average of emotional exhaustion is 3.353 and maximum is 4.8 which are good. And the average of turnover intention is 3.840 and maximum is 5.0 which are good. Median of abusive supervision is 3.400 and maximum is 4.8 which is good and the median of emotional exhaustion is 3.500 which is nearer to the maximum 4.8 it is also considered good. The median of turnover intension is 3.800 and maximum is 5.0 which are good. Standard deviation of abusive supervision is .7128, emotional exhaustion is .8121 and turnover intention is .7023 which is acceptable.

\begin{tabular}{|l|l|l|l|l|}
\hline \multicolumn{5}{|l|}{ Table No 11: Model Summary } \\
\hline Model & $\mathbf{R}$ & $\begin{array}{l}\text { R } \\
\text { Square }\end{array}$ & $\begin{array}{l}\text { Adjusted } \\
\text { R Square }\end{array}$ & $\begin{array}{l}\text { Std. Error of Estimate } \\
\text { the Ex }\end{array}$ \\
\hline 1 & $.758^{\mathrm{a}}$ & .575 & .560 & .4661 \\
\hline
\end{tabular}

a. Predictors: (Constant), EE, AS 
Table 11 shows the model summary. The adjusted R square value which is around $50 \%$ is considered to be worthy. The adjusted $\mathrm{R}$ square is 0.56 which mean that $56 \%$ dependent variable is being explained by these independent variables.

\begin{tabular}{|c|c|c|c|c|c|c|}
\hline \multicolumn{7}{|c|}{ Table No 12: ANOVA ${ }^{\text {a }}$} \\
\hline \multicolumn{2}{|c|}{ Model } & $\begin{array}{l}\text { Sum of } \\
\text { Square } \\
\text { S }\end{array}$ & Df & $\begin{array}{l}\text { Mean } \\
\text { Square }\end{array}$ & $\mathbf{F}$ & Sig. \\
\hline \multirow{3}{*}{$\mathbf{1}$} & Regressio & 16.720 & 2 & 8.360 & $\begin{array}{l}38.48 \\
1\end{array}$ & $.000^{\mathrm{b}}$ \\
\hline & Residual & 12.384 & 57 & .217 & & \\
\hline & otal & 29.104 & 59 & & & \\
\hline
\end{tabular}

a. Dependent Variable: TI

b. Predictors: (Constant), EE, AS

In the above table no 12 depicts the ANOVA statistics. The $\mathrm{F}$ value is 38.481 and significant value is .000 which is appropriate.

\begin{tabular}{|c|c|c|c|c|c|}
\hline \multicolumn{6}{|c|}{ Table No 13: Coefficients ${ }^{\text {a }}$} \\
\hline \multirow[b]{2}{*}{ Model } & $\begin{array}{l}\text { Unsta } \\
\text { Coeffi }\end{array}$ & $\begin{array}{l}\text { lardize } \\
\text { ents }\end{array}$ & \begin{tabular}{|l|}
$\begin{array}{l}\text { Standardiz } \\
\text { ed }\end{array}$ \\
Coefficient \\
S
\end{tabular} & \multirow[t]{2}{*}{ t } & \multirow[b]{2}{*}{ Sig. } \\
\hline & B & $\begin{array}{l}\text { Std. } \\
\text { Error }\end{array}$ & Beta & & \\
\hline \begin{tabular}{|l|l}
1 & (Constant) \\
\end{tabular} & 1.372 & .305 & & 4.493 & .000 \\
\hline AS & .226 & .113 & .229 & 2.004 & .050 \\
\hline EE & .509 & .099 & .588 & 5.148 & .000 \\
\hline
\end{tabular}

\section{a. Dependent Variable: TI}

In coefficient the independent variable abusive supervision has positive and significant effect on the dependent variable which is turnover intention. Table shows the value in which Abusive Supervision T value is 2.004 which is greater than 1.96 and sig value is .050 which is equal to $5 \%$ and in case of emotional exhaustion the $\mathrm{T}$ value is 5.148 and significant value is .000 which shows the positive and significant effect with the dependent variable turnover intention.

\begin{tabular}{|l|l|l|l|l|}
\hline \multicolumn{5}{|l|}{ Table No 14: Model Summary } \\
\hline Model & $\mathbf{R}$ & $\begin{array}{l}\text { R } \\
\text { Square }\end{array}$ & $\begin{array}{l}\text { Adjusted } \\
\text { R Square }\end{array}$ & $\begin{array}{l}\text { Std. Error } \\
\text { of the } \\
\text { Estimate }\end{array}$ \\
\hline 1 & $.759^{\mathrm{a}}$ & .576 & .553 & .4695 \\
\hline
\end{tabular}

a. Predictors: (Constant), Moderator, AS, EE Adjusted $\mathrm{R}$ square is .553 which means that $55 \%$ dependent variable is being explained by these independent variables.

\begin{tabular}{|l|l|l|l|l|l|l|}
\hline \multicolumn{2}{|l|}{ Table No 15: $\boldsymbol{A N O} \boldsymbol{V A}^{\boldsymbol{a}}$} \\
\hline \multicolumn{1}{|l|}{$\begin{array}{l}\text { Model } \\
\mathbf{1}\end{array}$} & $\begin{array}{l}\text { Sum of } \\
\text { Squares }\end{array}$ & $\begin{array}{l}\text { Mean } \\
\text { Square }\end{array}$ & $\mathbf{F}$ & Sig. \\
\hline & $\begin{array}{l}\text { Regressio } \\
\text { nesidual }\end{array}$ & 16.762 & 3 & 5.587 & 25.350 & $.000^{\mathrm{b}}$ \\
\hline & $\begin{array}{l}\text { Residual } \\
\text { Total }\end{array}$ & 29.104 & 56 & .220 & & \\
\hline
\end{tabular}

a. Dependent Variable: TI

b. Predictors: (Constant), Moderator, AS, EE

In the above table the $F$ value is 25.350 which are nearer to the maximum value which is 38.48 and significant value is .000 which is quite good.

\begin{tabular}{|c|c|c|c|c|c|}
\hline \multicolumn{6}{|c|}{ Table No 15: Coefficients ${ }^{a}$} \\
\hline \multirow[b]{2}{*}{ Model } & \multicolumn{2}{|c|}{$\begin{array}{l}\text { Unstandardized } \\
\text { Coefficients }\end{array}$} & \begin{tabular}{|l|} 
Standardiz \\
ed \\
Coefficient \\
s
\end{tabular} & & \\
\hline & B & \begin{tabular}{|l|} 
Std. \\
Error
\end{tabular} & Beta & $\mathbf{t}$ & Sig. \\
\hline \begin{tabular}{l|l}
1 & (Constan \\
t)
\end{tabular} & .881 & 1.177 & & .749 & .457 \\
\hline AS & .373 & 359 & .378 & 1.038 & .304 \\
\hline $\mathbf{E E}$ & .663 & .371 & .766 & 1.788 & .079 \\
\hline \begin{tabular}{|l|} 
Moderat \\
or
\end{tabular} & -.045 & .104 & -.301 & -.432 & .668 \\
\hline
\end{tabular}

a) 1 Dependent variable: TI

In the above table the impact of moderator is negative because moderator beta value is negative 0.301 . The $t$ value is -.432 which is very far from 1.96 and sig value is .668 which is very less than $10 \%$. So, the moderator has no impact on the relationship.

\section{CONCLUSION}

This research was conducted at Rawalpindi on the topic impact of abusive supervision on turnover intention with the moderating factor of emotional exhaustion. The main purpose of this study is to know the perception about the abusive supervision, to identify that how abusive supervision affects the emotional exhaustion which leads the turnover intention. The researcher tries to find out the perception of people about the abusive supervision. In Rawalpindi district there is an organization from where data is collected and people work under the supervision of their bosses. In private firm's bosses tries to get hard work from their employees. Due to which mainly they get strict with their colleagues. This analysis has provided a wealth of sensible 
implications that organizations ought to utilize to maximize individual and structure productivity by reducing and preventing abusive oversight. The negative effects on every individual worker, whether or not they are the maltreated or the abused, trickle down throughout the whole organization. It's within the hands of the organization to prevent this negative spiral, ideally before it starts. In this research, researcher find that boss behavior with their employees is not bad but it varies from personality to personality.

\section{REFERENCES}

1. Anam Javeed | Dr. Sany Sanuri bin Mohd Mokhatr | Dr. Ismail bin Lebai Othman "Impact of Product Packaging Cues on Product Quality Perceptions: Empirical Evidence from Pakistani Shopping Malls" Published in International Journal of Trend in Scientific Research and Development (ijtsrd), ISSN: 2456-6470, Volume$2 \mid$ Issue-2 , February 2018, URL: http://www.ijtsrd.com/papers/ijtsrd9676.pdf

2. Barney, J. (1991). Firm resources and sustained competitive advantage. Journal of management, 17(1), 99-120.

3. Brown, S. P., \& Peterson, R. A. (1993). Antecedents and consequences of salesperson job satisfaction: Meta-analysis and assessment of causal effects. Journal of marketing research, 30(1), 63.

4. Carmeli, A., Meitar, R., \& Weisberg, J. (2006). Self-leadership skills and innovative behavior at work. International Journal of Manpower, 27(1), 75-90.

5. Coyne, I., \& Ong, T. (2007). Organizational citizenship behaviour and turnover intention: a cross-cultural study. The International Journal of Human Resource Management, 18(6), 1085-1097.

6. Demmig-Adams, B., Gilmore, A. M., \& Adams, W. (1996). Carotenoids 3: in vivo function of carotenoids in higher plants. The FASEB Journal, 10(4), 403-412.

7. Ferris, M. J., Muyzer, G., \& Ward, D. M. (1996). Denaturing gradient gel electrophoresis profiles of 16S rRNA-defined populations inhabiting a hot spring microbial mat community. Applied and Environmental Microbiology, 62(2), 340-346.

8. Ghadially, R., \& Kumar, P. (1986). Staying as single women. Social Welfare, 33(4), 10-12.
9. Halbesleben, J. R., \& Buckley, M. R. (2004). Burnout in organizational life. Journal of management, 30(6), 859-879.

10. Khan, M.Y., Wali, S.S, \& Ahmad, A. (2011), 'Measuring Stress among Employees of Wah Noble Pakistan Private Limited and Pakistan Tobacco Company Public Limited', Interdisciplinary Journal of Contemporary Research in Business, Oct 2011/3, No 6, pp 202215.

11. Konovsky, M. A., \& Pugh, S. D. (1994). Citizenship behavior and social exchange. Academy of management journal, 37(3), 656-669.

12. Lusch, R. F., \& Serpkenci, R. R. (1990). Personal differences, job tension, job outcomes, and store performance: A study of retail store managers. The Journal of Marketing, 85-101.

13. LeBlanc, M. M., \& Kelloway, E. K. (2002). Predictors and outcomes of workplace violence and aggression. Journal of Applied Psychology, 87(3), 444.

14. Liu, A., Tegmark, M., Bowman, J., Hewitt, J., \& Zaldarriaga, M. (2009). An improved method for 21-cm foreground removal. Monthly Notices of the Royal Astronomical Society, 398(1), 401-406.

15. Liu, B. (2010). Uncertain risk analysis and uncertain reliability analysis. Journal of Uncertain Systems, 4(3), 163-170.

16. Lovell, S. E., Kahn, A. S., Anton, J., Davidson, A., Dowling, E., Post, D., \& Mason, C. (1999). Does gender affect the link between organizational citizenship behavior and performance evaluation? Sex Roles, 41(5-6), 469478.

17. Maslach, C., \& Jackson, S. E. (1981). 1986. The Maslach Burnout Inventory.

18. Mathieu, C., \& Babiak, P. (2016). Corporate psychopathy and abusive supervision: Their influence on employees' job satisfaction and turnover intentions. Personality and Individual Differences, 91, 102-106.

19. Meyer, J. P., \& Allen, N. J. (1991). A threecomponent conceptualization of organizational commitment. Human resource management review, 1(1), 61-89.

20. Milam, A. C., Spitzmueller, C., \& Penney, L. M. (2009). Investigating individual differences among targets of workplace incivility. Journal of occupational health psychology, 14(1), 58.

21. Mubeen, S. H. A. H. I. D., Naz, M. A. M. M. O. N. A., \& Rahman, G. A. U. H. A. R. (2013). A 
note on k-hypergeometric differential equations. J. Inequal. Spec. Funct, 4(3), 38-43.

22. Namie, G. (2007). The challenge of workplace bullying. Employment Relations Today, 34(2), 4351.

23. Neuman, J. H., \& Baron, R. A. (1998). Workplace violence and workplace aggression: Evidence concerning specific forms, potential causes, and preferred targets. Journal of management, 24(3), 391-419.

24. Netemeyer, R. G., Boles, J. S., McKee, D. O., \& McMurrian, R. (1997). An investigation into the antecedents of organizational citizenship behaviors in a personal selling context. The Journal of Marketing, 85-98.

25. Nishimura, D. Y., Swiderski, R. E., Alward, W. L., Searby, C. C., Patil, S. R., Bennet, S. R., \& Sheffield, V. C. (1998). The forkhead transcription factor gene FKHL 7 is responsible for glaucoma phenotypes which map to $6 \mathrm{p} 25$. Nature genetics, 19(2).

26. Pradhan, S., \& Jena, L. K. (2017). Effect of abusive supervision on employee's intention to quit and the neutralizing role of meaningful work in Indian IT organizations. International Journal of Organizational Analysis, (just-accepted), 00-00.

27. Rivest, R. L., \& Shamir, A. (1996, April). PayWord and MicroMint: Two simple micropayment schemes. In International Workshop on Security Protocols (pp. 69-87). Springer, Berlin, Heidelberg.

28. Rosenfeld, D. (2000). Suppression of rain and snow by urban and industrial air pollution. Science, 287(5459), 1793-1796.

29. Sabine, C. L., Feely, R. A., Gruber, N., Key, R. M., Lee, K., Bullister, J. L., ... \& Millero, F. J. (2004). The oceanic sink for anthropogenic CO2. science, 305(5682), 367-371.

30. Saleem, I., Ahmed, R., \& Saleem, N. (2016). Mediating Role of Work Exhaustion: The Missing Linchpin to Address Employee's Turnover.

31. Schaufeli, W. B., Leiter, M. P., \& Maslach, C. (2009). Burnout: 35 years of research and practice. Career development international, 14(3), 204-220.

32. Schyns, B., \& Schilling, J. (2013). How bad are the effects of bad leaders? A meta-analysis of destructive leadership and its outcomes. The Leadership Quarterly, 24(1), 138-158.

33. Temel, J. S., Greer, J. A., Muzikansky, A., Gallagher, E. R., Admane, S., Jackson, V. A., ... \& Billings, J. A. (2010). Early palliative care for patients with metastatic non-small-cell lung cancer. New England Journal of Medicine, 363(8), 733-742.

34. Tepper, B. J. (2007). Abusive supervision in work organizations: Review, synthesis, and research agenda. Journal of Management, 33(3), 261-289.

35. Tepper, B. J., Simon, L., \& Park, H. M. (2017). Abusive supervision. Annual Review of Organizational Psychology and Organizational Behavior, 4, 123-152.

36. Zapf, D., \& Gross, C. (2001). Conflict escalation and coping with workplace bullying: A replication and extension. European journal of work and organizational psychology, 10(4), 497-522.

37. Zellars, K. L., Tepper, B. J., \& Duffy, M. K. (2002). Abusive supervision and subordinates' organizational citizenship behavior. Journal of Applied Psychology, 87(6), 1068. 